\title{
Feedback, welzijn van verplegend personeel en kwaliteit van zorg in ziekenhuizen
}

\author{
Roel Schouteten, Suzanne Giesbers, Erik Poutsma, Beatrice van der Heijden \& Theo \\ van Achterberg*
}

Ziekenhuizen gebruiken in toenemende mate feedback over kwaliteitsindicatoren als instrument om de zorgkwaliteit te verbeteren. De onderliggende aanname is dat feedback over kwaliteitsindicatoren aan verpleegkundigen hen in staat stelt om hun eigen (manier van) werk(en) te beoordelen en aan te passen. Echter, een sterke focus op enkel kwantitatief meetbare kwaliteitsindicatoren kan ook een vervreemdend en demotiverend effect hebben. In deze studie onderzoeken we op basis van een voor- en nameting bij vier ziekenhuisafdelingen $(N=77)$ op welke manier de implementatie van frequente feedback bijdraagt aan het welzijn van de verpleegkundigen en de zorgkwaliteit. Op basis van attributietheorie, de feedbackomgeving en het Job DemandsResources model laten we zien dat feedback over kwaliteitsindicatoren niet meteen leidde tot een verbetering van het welzijn en de zorgkwaliteit. De manier waarop de verpleegkundigen de feedback attribueren, de context waarbinnen de feedback wordt gegeven en de mate waarin de feedback als extra belasting (job demand) wordt ervaren, blijken wél van invloed op het welzijn en de zorgkwaliteit. Dat betekent dat het van belang is om feedback op een positieve manier in te zetten ter verbetering van het welzijn van verpleegkundigen en de zorgkwaliteit.

\section{Inleiding en probleemstelling}

Ziekenhuizen gebruiken in toenemende mate feedback over de scores op kwaliteitsindicatoren als een manier om de kwaliteit van zorg te verbeteren. Verbetering van kwaliteitszorg is een essentieel onderdeel van ziekenhuismanagement, want vanuit de politiek en overheid (Inspectie voor de Gezondheidszorg, 2017), zorgverzekeraars en patiënten(verenigingen) wordt er voortdurend om transparantie gevraagd als het gaat om de kwaliteit van de zorg. Ook verenigingen van ziekenhuizen hebben programma's ontwikkeld ter verbetering van de zorgkwaliteit en waarin transparantie over kwaliteitsindicatoren centraal staat, bijvoorbeeld het programma 'Kwaliteitsvenster' van de Nederlandse Vereniging van Zieken-

* Roel Schouteten is verbonden aan het Institute for Management Research (IMR) van de Radboud Universiteit. E-mail: r.schouteten@fm.ru.nl. Suzanne Giesbers werkt bij het Canisius Wilhelmina Ziekenhuis in Nijmegen en is als promovendus verbonden aan het IMR. Erik Poutsma is verbonden aan het Institute for Management Research van de Radboud Universiteit. Beatrice van der Heijden is verbonden aan de Radboud Universiteit (Institute for Management Research), en is tevens verbonden aan de Open Universiteit en Kingston University (UK). Theo van Achterberg is verbonden aan het Academisch Centrum voor Verpleeg- en Vroedkunde aan de KU Leuven, en is tevens verbonden aan Radboudumc in Nijmegen en de Universiteit van Uppsala (Zweden). 
huizen (NVZ) en 'Sturen op kwaliteit' van de Nederlandse Federatie van Universitair Medische Centra (NFU). Over een groot aantal indicatoren moeten ziekenhuizen informatie aanleveren aan de diverse instanties, zoals informatie over valincidenten, doorligwonden, pijnscores, et cetera. Het idee achter het verzamelen van dergelijke gegevens is dat de informatie kan worden gebruikt om de zorgkwaliteit transparant te maken en te verbeteren (Berwick et al., 2003; Botje et al., 2016; Ikkersheim \& Koolman, 2012). Op basis van een uitgebreide literatuurstudie concluderen De Vos et al. (2009) dat het geven van feedback één van de meest gehanteerde manieren is om kwaliteitsindicatoren te gebruiken voor verbetering van de kwaliteit van zorg. In dit artikel beschrijven we de uitkomsten van een studie die gericht is op het verkrijgen van inzicht in de manier waarop het geven van feedback over kwaliteitsindicatoren aan verpleegkundigen bijdraagt aan het verbeteren van zorgkwaliteit. Meer specifiek rapporteren we uitkomsten van een onderzoek naar het effect van deze feedback op het welzijn van de verpleegkundigen en de zorgkwaliteit die ze leveren.

De onderliggende aanname is dat feedback over kwaliteitsindicatoren aan verpleegkundigen hen in staat stelt om hun eigen (manier van) werk(en) te beoordelen en aan te passen (Flottorp et al., 2010). Er is echter nog maar weinig empirische ondersteuning voor deze aanname (Van der Veer et al., 2010), en een literatuurstudie van Ivers et al. (2012) laat op basis van een zogenaamde Cochrane review bovendien zien dat de gevonden effecten variëren van weinig of geen verband tot een sterk verband, maar ook dat er nog weinig onderzoek is gedaan dat inzicht biedt in de onderliggende mechanismen. Daarnaast laten andere studies (Doherty, 2009; Struijs \& Vathorst, 2009) zien dat er een vervreemdend en demotiverend effect van feedback over kwaliteitsindicatoren kan uitgaan. Verpleegkundigen kunnen naar aanleiding van de veelal kwantitatieve kwaliteitsindicatoren het gevoel krijgen dat alle zorgactiviteiten die niet in meetbare getallen worden uitgedrukt, zoals het geruststellen van patiënten, minder belangrijk zijn. Een mogelijk gevolg hiervan kan zijn dat het welzijn van de verpleegkundigen afneemt (McCann et al., 2015). In de gezondheidszorg wordt het welzijn van de medewerkers echter cruciaal geacht voor de effectiviteit, efficiency en kwaliteit van de zorg (Franco et al., 2002; Aiken et al., 2014). Bovendien kan verminderd welzijn onder verpleegkundigen ook tot een hoger verloop leiden (Hasselhorn et al., 2008; Mark \& Smith, 2012).

Om deze relaties tussen feedback over kwaliteitsindicatoren, welzijn van verpleegkundigen en de kwaliteit van zorg te onderzoeken hebben we een conceptueel model ontwikkeld (Giesbers et al., 2013) dat we in vier ziekenhuizen hebben gebruikt als basis voor onze dataverzameling. In dit model fungeren de interpretaties van verpleegkundigen en de feedbackomgeving als mediërende factoren in de relatie tussen feedback en de kwaliteit van zorg. Daarmee sluiten we aan bij actuele debatten over de mechanismen die een rol spelen in de relatie tussen de implementatie van HR-activiteiten en organisatieprestaties (zie bijv. Paauwe et al., 2013), door in te gaan op hoe feedback kan bijdragen aan betere kwaliteit van zorg. Kwaliteit van zorg is in dit onderzoek uitgedrukt in termen zoals die tot uiting komen in de kwaliteitsindicatoren die binnen de sector worden gebruikt om de kwaliteit te meten (Inspectie voor de Gezondheidszorg, 2017). Onder feedback over kwaliteitsindicatoren verstaan we dan de activiteiten binnen zie- 
kenhuizen die de resultaten van de kwaliteitsmetingen terugkoppelen aan de verpleegkundigen.

Voor ziekenhuizen, maar ook voor andere zorginstellingen is deze studie relevant vanwege de inzichten in de manier waarop feedback als verbeterinstrument kan bijdragen aan een betere zorg, maar ook kan leiden tot een beter welzijn bij verpleegkundigen.

In de volgende paragraaf bespreken we het conceptuele model dat aan het onderzoek ten grondslag ligt. Vervolgens komt de methodologie aan bod, gevolgd door de resultaten van het onderzoek. Ten slotte bespreken we de belangrijkste conclusies en aanbevelingen van onze studie.

\section{Mechanismen in de relatie tussen feedback en zorgkwaliteit}

Zowel in literatuur over de effectiviteit van feedback (zie bijv. Kluger \& DeNisi, 1996) als in de HRM-literatuur (zie bijv. Boxall \& Macky, 2009; Guest, 2002; Paauwe, 2009; Peccei et al., 2013) wordt de functie van welzijn als mediërende variabele tussen een interventie (in dit geval feedback) en prestaties (zorgkwaliteit) onderkend. Welzijn kan langs verschillende dimensies worden gedefinieerd (De Jonge \& Schaufeli, 1998). In dit onderzoek is er sprake van welzijn in het geval van weinig burn-out en veel bevlogenheid bij de verpleegkundigen (Le Blanc et al., 2001).

Als mediërende variabele is er ook een belangrijke rol weggelegd voor de percepties van medewerkers met betrekking tot de feedback die ze ontvangen. Ten eerste, is het van belang of de feedback in kwestie daadwerkelijk wordt ervaren als een heldere aanwijzing om het werk beter te doen, of als een manier om medewerkers onder druk te zetten. Dit sluit aan bij de mechanismen van het Job Demands-Resources (JD-R) model (Demerouti et al., 2001). Volgens dit model hebben job demands, zijnde de eisen die aan het werk worden gesteld en die energie van de medewerker vergen, een negatief effect op het welzijn van medewerkers, hetgeen zich uit in een hogere mate van burn-out en een afname in bevlogenheid. Job resources, zijnde de mogelijkheden die in het werk gelegen zijn om aan de eisen van het werk te voldoen, hebben juist een positief effect op het welzijn. Op basis van deze redenering kan worden verondersteld dat wanneer de feedback als belastend (job demand) wordt ervaren, dit een negatief effect heeft op het welzijn van de specifieke medewerker. Dit is bijvoorbeeld het geval als de feedback laat zien dat de resultaten van de verpleegkundigen niet in lijn zijn met de beoogde doelen en er nadrukkelijk op wordt aangedrongen die doelen stringent na te streven. Hierdoor worden zij onder druk gezet om anders of harder te werken om de doelen te bereiken. Andersom kan feedback die als ondersteunend (job resource) wordt ervaren, juist een positief effect hebben op welzijn. Dit is bijvoorbeeld het geval als de feedback inzicht geeft in de manier waarop verpleegkundigen hun werk anders of beter kunnen doen.

Of feedback als belastend of ondersteunend wordt ervaren, wordt in de tweede plaats voor een deel bepaald door de interpretatie van medewerkers van de reden waarom zij feedback krijgen over de resultaten op de kwaliteitsindicatoren. Volgens de redenering van Nishii et al. (2008) kunnen HR-activiteiten, waarvan feedback een voorbeeld is, namelijk op verschillende manieren worden geattribu- 
eerd en heeft dat verschillende effecten voor de interpretatie van de feedback. Nishii et al. (2008) maken een onderscheid naar externe en interne attributies. Er is sprake van externe attributie als verpleegkundigen denken dat de feedback over kwaliteitsindicatoren wordt gegeven omdat dat wordt opgelegd door actoren buiten de afdeling of het ziekenhuis, bijvoorbeeld de inspectie of zorgverzekeraars. Het management heeft daar dan geen invloed op, omdat ze het simpelweg moeten uitvoeren om aan de eisen te voldoen. Verpleegkundigen die deze interpretatie van het waarom van de feedback hebben, zullen de feedback, en het moeten voldoen aan de extern opgelegde verplichtingen, ervaren als een extra belasting in hun werk (job demand) (Giesbers et al., 2013).

Bij interne attributies denken verpleegkundigen dat de feedback over de kwaliteitsindicatoren wordt gegeven vanwege keuzes die het management of de leidinggevende maakt omtrent de kwaliteitsverbetering. Hierbij onderscheiden Nishii et al. (2008) zogenaamde commitment-focused en control-focused attributies. Als verpleegkundigen ervaren dat de feedback wordt gegeven om hen in staat te stellen (de kwaliteit van) hun werk te verbeteren, dan is er sprake van een commitment-focused attributie. Verpleegkundigen ervaren de feedback dan als een ondersteuning bij het uitvoeren van hun werk (dus als een job resource). Maar als de verpleegkundigen ervaren dat de feedback niet vrijblijvend wordt gegeven om de kwaliteit van het werk te monitoren en beoordelen, dan is er sprake van een control-focused attributie. In dat geval wordt de feedback ervaren als een (extra) werkbelasting (en dus als een job demand) (Giesbers et al., 2013). Een derde factor die bepalend is voor de ervaring van de feedback door de verpleegkundigen, is de context waarbinnen de feedback wordt gegeven. Deze zogenaamde feedback environment (Dahling et al., 2012) is van invloed op de uitkomsten van de feedback, in het bijzonder op de manier waarop de werknemers de feedback ervaren, en daarmee op hun welzijn en prestaties. In een sterke feedbackomgeving zijn werknemers eraan gewend om regelmatig formele en informele feedback te ontvangen, te vragen en te gebruiken om (de kwaliteit van) hun werk te verbeteren (Anseel \& Lievens, 2007; Steelman et al., 2004). Hieruit leiden we af dat als verpleegkundigen feedback ontvangen in een sterke feedback-omgeving, zij de feedback eerder als een ondersteuning (dus als een job resource) ervaren, hetgeen een positief effect heeft op hun welzijn en daarmee op de kwaliteit van de zorg die ze leveren.

Op basis van de beschreven mechanismen verwachten we dat feedback over kwaliteitsindicatoren, via de ervaringen van de verpleegkundigen (als een job demand of juist als een resource), van invloed is op hun welzijn en daarmee op de kwaliteit van de zorg die zij leveren. Daarbij wordt de ervaring van de feedback bepaald door de reden waarom de feedback wordt gegeven (attributie) en door de feedbackomgeving (Giesbers et al., 2013). Dit is schematisch weergegeven in figuur 1. 


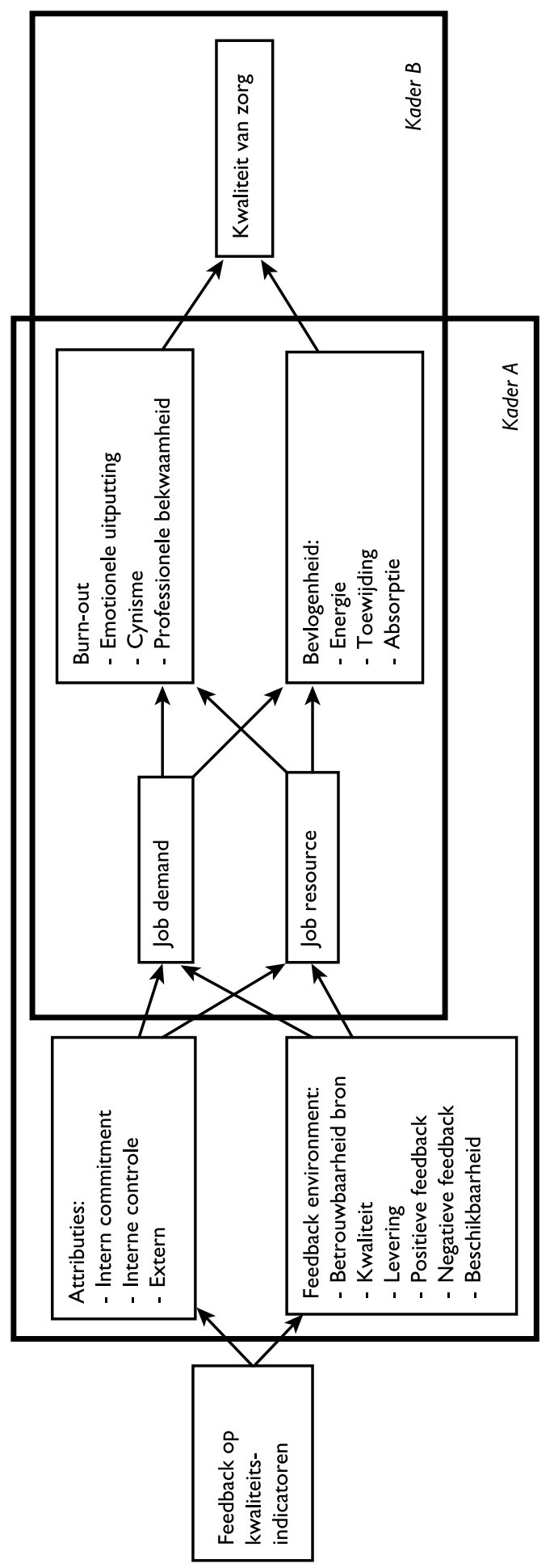

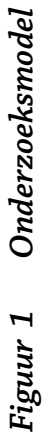




\section{Methodologie}

\section{Respondenten en dataverzameling}

Om te onderzoeken op welke manier het geven van feedback over kwaliteitsindicatoren aan verpleegkundigen bijdraagt aan hun welzijn en aan de kwaliteit van de zorg die zij leveren, hebben we kwantitatieve gegevens verzameld bij vier afdelingen in drie Nederlandse opleidingsziekenhuizen. In elk van deze afdelingen werd er gedurende een periode van vier maanden op regelmatige basis zowel mondelinge als schriftelijke feedback over kwaliteitsindicatoren gegeven aan de verpleegkundigen. Omwille van de vergelijkbaarheid hebben we overeenkomstige ziekenhuisafdelingen met snijdende specialismen meegenomen. In deze afdelingen werd nog niet eerder op gestructureerde wijze feedback over kwaliteitsindicatoren aan verpleegkundigen gegeven. De vier afdelingen in het onderzoek deden vrijwillig mee. De ziekenhuizen waaruit de afdelingen afkomstig zijn variëren in omvang tussen 643 en 1070 bedden en tussen 2640 en 2915 medewerkers. Tabel 1 geeft een overzicht van de demografische kenmerken van de deelnemende afdelingen en van de manier waarop we data hebben verzameld.

De feedbackinterventie in de vier afdelingen was vergelijkbaar. De tweede auteur ontwikkelde een raamwerk voor het ontwerp en de inhoud van de feedback per afdeling, om ervoor te zorgen dat de feedbackinterventie binnen alle afdelingen vergelijkbaar was. Volgens dat raamwerk werd er in elke afdeling regelmatig (minstens één keer per twee weken) mondelinge en schriftelijke feedback gegeven aan de verpleegkundigen over maximaal zes kwaliteitsindicatoren (zie tabel 2). Per kwaliteitsindicator werd er een doel bepaald en werden de resultaten steeds weergegeven in een grafiek. De afdelingsmanager was verantwoordelijk voor een aantal keuzes omtrent de manier waarop de feedback werd gegeven: ten aanzien van welke kwaliteitsindicatoren, welke doelen per indicator, hoe de kwaliteitsindicatoren werden gemeten, en hoe de feedback (schriftelijk, mondeling) werd gegeven. Tabel 2 geeft een overzicht van de keuzes per afdeling.

Tabel 1 Demografische kenmerken van de deelnemende afdelingen

\begin{tabular}{|c|c|c|c|c|}
\hline Afdeling & I & 2 & 3 & 4 \\
\hline Ziekenhuis & $\mathbf{A}$ & B & C & C \\
\hline \multicolumn{5}{|c|}{ Demografische kenmerken } \\
\hline $\begin{array}{l}\text { Aantal verpleeg- } \\
\text { kundigen op de } \\
\text { afdeling }\end{array}$ & 29 & 30 & 69 & 56 \\
\hline $\begin{array}{l}\text { Medisch specia- } \\
\text { lisme per afde- } \\
\text { ling }\end{array}$ & $\begin{array}{l}\text { Neurochirurgie en } \\
\text { orthopedie }\end{array}$ & Longchirurgie & $\begin{array}{l}\text { Urologie, plasti- } \\
\text { sche chirurgie en } \\
\text { gynaecologie }\end{array}$ & $\begin{array}{l}\text { Algemene } \\
\text { chirurgie }\end{array}$ \\
\hline \multicolumn{5}{|c|}{ Kenmerken van de onderzoekspopulatie } \\
\hline $\begin{array}{l}\text { Vragenlijsten } \\
\text { (voor- en name- } \\
\text { ting volledig } \\
\text { ingevuld) }\end{array}$ & $\begin{array}{l}\text { Respons: } n=19 \\
\text { Man: } n=2 \\
\text { Vrouw: } n=17 \\
\text { Gemiddelde leeftijd: } 33,3\end{array}$ & $\begin{array}{l}\text { Respons: } n=17 \\
\text { Man: } n=3 \\
\text { Vrouw: } n=14 \\
\text { Gemiddelde leef- } \\
\text { tijd: } 29,2\end{array}$ & $\begin{array}{l}\text { Respons: } n=22 \\
\text { Man: } n=2 \\
\text { Vrouw: } n=20 \\
\text { Gemiddelde leef- } \\
\text { tijd: } 35,4\end{array}$ & $\begin{array}{l}\text { Respons: } n=19 \\
\text { Man: } n=2 \\
\text { Vrouw: } n=17 \\
\text { Gemiddelde leeftijd: } \\
31,9\end{array}$ \\
\hline
\end{tabular}


Tabel 2 Kenmerken van de feedback per afdeling

\begin{tabular}{|c|c|c|c|c|}
\hline Afdeling & I & 2 & 3 & 4 \\
\hline Ziekenhuis & $\mathbf{A}$ & B & C & C \\
\hline Bron & $\begin{array}{l}\text { Steekproef van de } \\
\text { elektronische } \\
\text { patiëntendossiers } \\
\text { van opgenomen } \\
\text { patiënten }\end{array}$ & $\begin{array}{l}\text { Een kwaliteitsregi- } \\
\text { stratie van alle } \\
\text { opgenomen } \\
\text { patiënten. Alle } \\
\text { data in deze } \\
\text { registratie worden } \\
\text { dagelijks inge- } \\
\text { voerd door de } \\
\text { verpleegkundigen } \\
\text { op de afdeling. }\end{array}$ & $\begin{array}{l}\text { De elektronische } \\
\text { patiëntendossiers } \\
\text { van alle opge- } \\
\text { nomen patiënten }\end{array}$ & $\begin{array}{l}\text { De elektronische } \\
\text { patiëntendossiers } \\
\text { van alle opge- } \\
\text { nomen patiënten }\end{array}$ \\
\hline $\begin{array}{l}\text { Functie die de } \\
\text { feedback geeft }\end{array}$ & $\begin{array}{l}\text { Afdelingshoofd of } \\
\text { senior verpleeg- } \\
\text { kundige }\end{array}$ & $\begin{array}{l}\text { Afdelingshoofd of } \\
\text { senior verpleeg- } \\
\text { kundige }\end{array}$ & $\begin{array}{l}\text { Afdelingshoofd of } \\
\text { senior verpleeg- } \\
\text { kundige }\end{array}$ & $\begin{array}{l}\text { Afdelingshoofd of } \\
\text { senior verpleegkun- } \\
\text { dige }\end{array}$ \\
\hline $\begin{array}{l}\text { Format en } \\
\text { frequentie van de } \\
\text { feedback op papier }\end{array}$ & $\begin{array}{l}\text { Poster in de } \\
\text { teamkamer } \\
\text { Een keer per twee } \\
\text { weken vernieuwd }\end{array}$ & $\begin{array}{l}\text { E-mail } \\
\text { Een keer per twee } \\
\text { weken }\end{array}$ & $\begin{array}{l}\text { E-mail (als bijlage } \\
\text { bij de wekelijkse } \\
\text { nieuwsbrief) } \\
\text { Een keer per week } \\
\text { Poster in de } \\
\text { teamkamer } \\
\text { Een keer per week } \\
\text { vernieuwd }\end{array}$ & $\begin{array}{l}\text { E-mail (als bijlage } \\
\text { bij de wekelijkse } \\
\text { nieuwsbrief) } \\
\text { Een keer per week }\end{array}$ \\
\hline $\begin{array}{l}\text { Format en } \\
\text { frequentie van de } \\
\text { mondelinge feed- } \\
\text { back }\end{array}$ & $\begin{array}{l}\text { Presentatie en } \\
\text { discussie tijdens } \\
\text { team briefings in } \\
\text { de ochtend } \\
\text { Twee keer per } \\
\text { twee weken }\end{array}$ & $\begin{array}{l}\text { Presentatie en } \\
\text { discussie tijdens } \\
\text { pauzes } \\
\text { Een keer per twee } \\
\text { weken }\end{array}$ & $\begin{array}{l}\text { Presentatie en } \\
\text { discussie tijdens } \\
\text { teamoverleg of } \\
\text { debriefings in de } \\
\text { middag } \\
\text { Sporadisch }\end{array}$ & $\begin{array}{l}\text { Presentatie en } \\
\text { discussie tijdens } \\
\text { teamoverleg of } \\
\text { debriefings in de } \\
\text { middag } \\
\text { Sporadisch }\end{array}$ \\
\hline $\begin{array}{l}\text { Inhoud: kwaliteitsin- } \\
\text { dicatoren en gere- } \\
\text { lateerde doelstel- } \\
\text { lingen (tussen } \\
\text { haakjes) }\end{array}$ & $\begin{array}{l}\text { Het percentage } \\
\text { patiënten dat is } \\
\text { gescreend op: het } \\
\text { (risico op) decu- } \\
\text { bitus (> 80\%) } \\
\text { pijn (> 90\%) } \\
\text { plotselinge achteruit- } \\
\text { gang (> 75\%) } \\
\text { Het percentage } \\
\text { patiënten dat } \\
\text { ernstige pijn } \\
\text { ervaarde tijdens } \\
\text { de opname (< } \\
5 \% \text { ) } \\
\text { Het aantal } \\
\text { patiënten dat } \\
\text { decubitus ontwik- } \\
\text { kelde tijdens de } \\
\text { opname (= 0) }\end{array}$ & $\begin{array}{l}\text { Het percentage } \\
\text { patiënten dat is } \\
\text { gescreend op: het } \\
\text { (risico op) decu- } \\
\text { bitus (> 90\%) } \\
\text { een (risico op) } \\
\text { delier (> 90\%) } \\
\text { het (risico op) } \\
\text { ondervoeding (> } \\
90 \% \text { ) } \\
\text { Het percentage } \\
\text { patiënten dat } \\
\text { geen ernstige pijn } \\
\text { ervaarde tijdens } \\
\text { de opname (> } \\
80 \% \text { ) } \\
\text { Het percentage } \\
\text { patiënten dat de } \\
\text { kwaliteit van zorg } \\
\text { beoordeelde met } \\
>7,5 \text { (> } 80 \% \text { ) }\end{array}$ & $\begin{array}{l}\text { Het percentage } \\
\text { patiënten dat is } \\
\text { gescreend op: het } \\
\text { (risico op) decu- } \\
\text { bitus (> 80\%) } \\
\text { het (risico op) } \\
\text { ondervoeding (> } \\
80 \% \text { ) } \\
\text { kwetsbaarheid bij } \\
\text { ouderen (> 80\%) } \\
\text { Het percentage } \\
\text { patiënten dat } \\
\text { ernstige pijn } \\
\text { ervaarde tijdens } \\
\text { de opname (< } \\
\text { l0\%) }\end{array}$ & $\begin{array}{l}\text { Het percentage } \\
\text { patiënten dat is } \\
\text { gescreend op: het } \\
\text { (risico op) decu- } \\
\text { bitus (> 80\%) } \\
\text { het (risico op) } \\
\text { ondervoeding (> } \\
80 \% \text { ) } \\
\text { kwetsbaarheid bij } \\
\text { ouderen (> } 80 \% \text { ) } \\
\text { Het percentage } \\
\text { patiënten dat } \\
\text { ernstige pijn } \\
\text { ervaarde tijdens } \\
\text { de opname (< } \\
\text { l0\%) }\end{array}$ \\
\hline
\end{tabular}

Voor de dataverzameling hebben we voorafgaand aan de feedbackinterventie en na vier maanden een online vragenlijst afgenomen. De verwachting is dat de feedbackinterventie na vier maanden is geïnternaliseerd. Hiermee kunnen we 
nagaan hoe de verpleegkundigen de feedback ervaren en welk duurzaam effect de feedback heeft op het welzijn van de verpleegkundigen. Van de 184 verpleegkundigen hebben 107 verpleegkundigen deelgenomen aan de voormeting (responspercentage: 85,2) en hebben 91 verpleegkundigen de vragenlijst van de nameting volledig ingevuld (responspercentage: 49,5 ). In totaal hebben 77 verpleegkundigen (respons: 41,8\%) beide vragenlijsten volledig ingevuld; deze groep respondenten vormt de hoofdmoot voor de analyses in deze studie.

\section{Operationalisatie}

Voor de dataverzameling hebben we een meetinstrument ontwikkeld, voor een deel op basis van bestaande instrumenten en voor een deel op basis van schalen die we zelf ontwikkeld en getoetst hebben in een pilotstudie (Giesbers et al., 2014). Als afhankelijke variabele hebben we aan de verpleegkundigen gevraagd hoe ze de gebruikelijke kwaliteit van zorg op hun afdeling beoordelen, gebruikmakend van een schaal van 1 tot 10, waarbij 1 verwijst naar de laagste score voor kwaliteit van zorg. Daarmee is dit een maat voor de gepercipieerde zorgkwaliteit door de verpleegkundigen zelf. Dit is een alternatief voor de scores op de kwaliteitscriteria, omdat die alleen beschikbaar waren op afdelingsniveau (en we te weinig afdelingen in het onderzoek hebben om daar multi-level analyses mee uit te voeren), maar ook op verschillende manieren en vanuit verschillende bronnen verzameld zijn (zie Tabel 2).

Het welzijn van de verpleegkundigen hebben we gemeten als burn-out en bevlogenheid. Burn-out wordt gekenmerkt door de dimensies emotionele uitputting, cynisme, en gevoelens van persoonlijke onbekwaamheid. We hebben het concept gemeten met de 16 items van de Utrechtse Burn-outschaal (UBOS, Cronbach's alpha = ,84; Schaufeli \& Bakker, 2004). De Cronbach's alpha's voor de dimensies emotionele uitputting, cynisme en gevoelens van persoonlijke bekwaamheid zijn respectievelijk ,88; ,64 en ,63. Bevlogenheid verwijst naar een positieve gemoedstoestand die wordt gekenmerkt door de dimensies energie (vigor), toewijding (dedication) en absorptie (opgaan in het werk). Dit concept hebben we gemeten met de 9 items van de korte Utrechtse Bevlogenheidsschaal (UBES-9, Cronbach's alpha = ,87; Schaufeli \& Bakker, 2003). De Cronbach's alpha's voor de dimensies zijn ,73 voor energie; ,80 voor toewijding; en ,78 voor absorptie. Om te bepalen of verpleegkundigen de feedback ervaren als een job demand of juist als een job resource, hebben we voortbouwend op het JD-R model (Demerouti et al., 2001) een nieuw instrument ontwikkeld (Giesbers et al., 2014). Het instrument bestaat uit 10 items, bestaande uit 5 items voor feedback als job resource (Cronbach's alpha $=, 85$ ) en 5 items voor feedback als job demand (Cronbach's alpha $=, 71$ ). Een voorbeeld-item voor feedback als job resource is 'Doordat de resultaten op de kwaliteitsindicatoren aan mij worden teruggekoppeld weet ik beter wat de doelen van het ziekenhuis zijn'. Een voorbeeld-item voor job demand is 'Doordat de resultaten op de kwaliteitsindicatoren aan mij worden teruggekoppeld voel ik een druk om te voldoen aan de kwaliteitsnormen die de indicatoren meten'.

Voor het bepalen van de attributies van de verpleegkundigen hebben we, voortbouwend op het gedachtegoed van Nishii et al. (2008), een nieuw instrument 
ontwikkeld (Giesbers et al., 2014). Een factoranalyse bevestigt het onderscheid naar drie vormen van attributies:

a commitment-focused attributie (de medewerkers denken dat het management de feedback geeft om de kwaliteit van de zorg en het welzijn van de medewerkers te verbeteren), Cronbach's alpha $=, 72$. Een voorbeelditem is: 'De resultaten op de kwaliteitsindicatoren worden aan mij teruggekoppeld, omdat mijn leidinggevende de kwaliteit van de zorg wil verbeteren.'

b control-focused attributie (de medewerkers denken dat de feedback wordt gegeven om kosten te besparen), Cronbach's alpha $=$,72. Een voorbeelditem is: 'De resultaten op de kwaliteitsindicatoren worden aan mij teruggekoppeld, omdat mijn leidinggevende zo veel mogelijk werk bij de verpleegkundigen wil neerleggen.'

c externe attributies (de medewerkers denken dat de feedback wordt gegeven om aan externe verplichtingen te voldoen), Cronbach's alpha $=, 69$. Een voorbeelditem is: 'De resultaten op de kwaliteitsindicatoren worden aan mij teruggekoppeld, omdat het ziekenhuis moet voldoen aan de eisen van de "buitenwereld (inspectie, zorgverzekeraars, AD top 100, etc.)".'

Voor het meten van de feedbackomgeving hebben we de door Anseel en Lievens (2007) naar het Nederlands vertaalde en gevalideerde korte versie van de Supervisor Feedback Environment Scale (SFES; Rosen et al., 2006) gebruikt. Deze schaal meet de feedbackomgeving aan de hand van zeven dimensies: betrouwbaarheid van de feedbackbron (source credibility), feedback-kwaliteit, feedbacklevering, geven van positieve feedback, geven van negatieve feedback, beschikbaarheid van informatie, en aanmoedigen van feedbackzoekgedrag. ${ }^{1}$ De Cronbach's alpha van de volledige schaal is,90. De Cronbach's alpha's van de dimensies zijn respectievelijk: ,83; ,85; ,87; ,85; ,71 en ,47. In de analyses gebruiken we de afzonderlijke dimensies.

In de vragenlijst zijn enkele vragen opgenomen die als controlevariabelen fungeren, zoals de specifieke afdeling waar de verpleegkundige werkt, functie, geslacht, leeftijd, ervaring, en aantal werkuren per week. Op basis van enkele voorbereidende analyses en correlatieanalyses blijken alleen het aantal werkuren per week en het aantal jaren werkervaring in het betreffende ziekenhuis significant samen te hangen met enkele van de burn-out- en bevlogenheidsdimensies in onze studie. Daarom is in alle vervolganalyses in deze studie gecontroleerd voor de invloed van deze twee controlevariabelen. De andere controlevariabelen hangen niet of nauwelijks samen met de variabelen in het onderzoek en zijn vanwege de relatief beperkte omvang van het aantal respondenten niet in de analyses meegenomen.

\section{Resultaten}

Tabel 3 geeft een overzicht van de gemiddelde scores op de schalen die gebruikt zijn in de analyse. Hierin zijn alleen de resultaten meegenomen van de verpleegkundigen die beide vragenlijsten hebben ingevuld. Uit tabel 3 blijkt dat de verpleegkundigen de kwaliteit van zorg op hun afdeling beoordelen met een ruime 7 als rapportcijfer. De bevlogenheid van de verpleegkundigen is hoog (tussen 
5,6 en 5,9 op een schaal van 1-7). De score op burn-out is redelijk laag, waarbij emotionele uitputting het hoogst scoort en gevoelens van persoonlijke onbekwaamheid het laagst. Het werk is enigszins vermoeiend, maar de verpleegkundigen hebben het gevoel dat ze bekwaam genoeg zijn om hun werk goed uit te kunnen voeren.

Opvallend in tabel 3 is het feit dat de scores in de nameting negatiever uitpakken dan in de voormeting. Het cijfer voor de kwaliteit van de geleverde zorg is (hoewel net niet significant) lager in de nameting. Ook de scores op bevlogenheid zijn lager; voor de dimensie energie is het verschil significant. De scores op burnout zijn significant hoger (voor gevoelens van persoonlijke bekwaamheid is het verschil niet significant). Op basis van het invoeren van feedback was de verwachting dat de kwaliteit van de zorg zou verbeteren, de bevlogenheid zou toenemen, en de burn-out zou verminderen. Op basis van deze cijfers kunnen we echter nog niets zeggen over de relatie tussen de implementatie van de feedback en deze resultaten. Om ons conceptuele model empirisch te toetsen hebben we met behulp van de PROCESS-macro van Hayes (www.afhayes.com) een groot aantal mediatieanalyses uitgevoerd.

\section{Tabel $3 \quad$ Schaalgemiddelden in de voor- en nameting $(n=77)$}

\begin{tabular}{lccc}
\hline Schaal & Voormeting & Nameting & Sig. (2-tailed) \\
\hline $\begin{array}{l}\text { Cijfer voor gebruikelijke kwaliteit van zorg op } \\
\text { mijn afdeling }\end{array}$ & 7,40 & 7,19 &, 059 \\
Feedback ervaren als job demand & & \\
Feedback ervaren als job resource & & 4,09 & \\
Externe attributie & 4,74 & \\
Intern commitment attributie & 5,80 & \\
Intern controle attributie & 4,83 & \\
SFES (overall gemiddelde feedback environment) & & 3,16 & \\
SFES: betrouwbaarheid van feedbackbron & 5,13 & \\
SFES: feedback-kwaliteit & 5,53 & \\
SFES: feedback-levering & & 5,35 & \\
SFES: geven van positieve feedback & 5,26 & \\
SFES: geven van negatieve feedback & & 4,84 & \\
SFES: beschikbaarheid van informatie & & 5,17 & \\
Bevlogenheid (overall schaal) & 4,59 & \\
Bevlogenheid: energie & 5,68 & 5,57 &, 060 \\
Bevlogenheid: toewijding & 5,77 & 5,61 &, 018 \\
Bevlogenheid: absorptie & 5,95 & 5,88 &, 368 \\
Burn-out (overall schaal) & 5,32 & 5,20 &, 247 \\
Burn-out: cynisme & 2,32 & 2,56 &, 000 \\
Burn-out: emotionele uitputting & 2,21 & 2,61 &, 000 \\
Burn-out: gevoelens van persoonlijke bekwaam- & 2,43 & 2,78 &, 000 \\
heid & 1,31 & 1,38 &, 203 \\
& & &
\end{tabular}

Om de mediatieanalyses uit te voeren hebben we ons model in twee delen geanalyseerd. In het eerste deel hebben we geanalyseerd of de mate waarin de feedback wordt ervaren als een job demand of job resource de relatie tussen 
enerzijds de attributies en de feedbackomgeving en anderzijds het welzijn van de verpleegkundigen (burn-out en bevlogenheid) medieert (zie kader A in figuur 1). In het tweede deel hebben we geanalyseerd of het welzijn van de verpleegkundigen (burn-out en bevlogenheid) een mediator is tussen de ervaring van de feedback als job demand of job resource en de kwaliteit van de zorg (zie kader $B$ in figuur 1).

In lijn met conventies (Baron \& Kenny, 1986) hebben we eerst op basis van gewone regressies bepaald of aan de voorwaarden voor mediatie is voldaan. Deze voorwaarden zijn dat de onafhankelijke variabele moet samenhangen met zowel de mediator als de afhankelijke variabele. Daarnaast moet de mediator samenhangen met de afhankelijke variabele. In deze regressieanalyses hebben we aantal werkuren per week en aantal jaren werkervaring in het betreffende ziekenhuis als controlevariabelen meegenomen. Voor de variabelen en relaties die aan de voorwaarden voldoen, hebben we mediatieanalyses uitgevoerd. Daarbij hebben we eveneens de score op de afhankelijke variabelen in de eerste meting meegenomen als controlevariabelen, omdat het waarschijnlijk is dat de waarde op de eerste meting hoog correleert met de waarde in de tweede meting. Op deze manier maken we optimaal gebruik van de onderzoeksopzet met twee metingen. De belangrijkste resultaten van de regressie- en mediatieanalyses zijn weergegeven in figuur 2 en bijbehorende tabel 4 . Elke pijl in figuur 2 geeft een significante relatie uit de regressieanalyses weer. De dikke pijlen duiden daarnaast op significante mediërende relaties. In de bijlage staat een detailoverzicht van de significante resultaten.

Uit figuur 2 blijkt dat wanneer verpleegkundigen de feedback als controle attribueren, de feedback als een demand wordt ervaren. Als de feedback als ondersteuning wordt geattribueerd, wordt de feedback meer als een job resource ervaren. Dit is in lijn met de verwachtingen. Daarbij kan de sterke relatie tussen de commitment-attributie en de ervaring van de feedback als job resource deels ook worden verklaard doordat de bewoordingen van een aantal items van beide constructen dicht tegen elkaar aan liggen (met vergelijkbare begrippen gerelateerd aan het verbeteren van de kwaliteit van zorg). Externe attributie hangt niet samen met de ervaring van feedback als job demand of resource.

De ervaring van feedback als job demand of resource hangt samen met de welzijnsdimensies. Hierbij valt op dat vooral de ervaring van de feedback als een demand samenhangt met zowel de burn-outdimensies (positieve samenhang) als de bevlogenheidsdimensies (negatieve samenhang); hoe meer de feedback als demand wordt ervaren, hoe hoger de scores op burn-out en hoe lager de scores op bevlogenheid. De ervaring van feedback als een resource hangt alleen positief samen met de bevlogenheidsdimensie energie.

Alle burn-outdimensies hangen significant samen met de ervaren zorgkwaliteit; hoe meer burn-out, hoe lager de ervaren zorgkwaliteit. De bevlogenheidsdimensies toewijding en energie hangen positief samen met de ervaren zorgkwaliteit; hoe meer toewijding en energie, hoe hoger de ervaren zorgkwaliteit. 


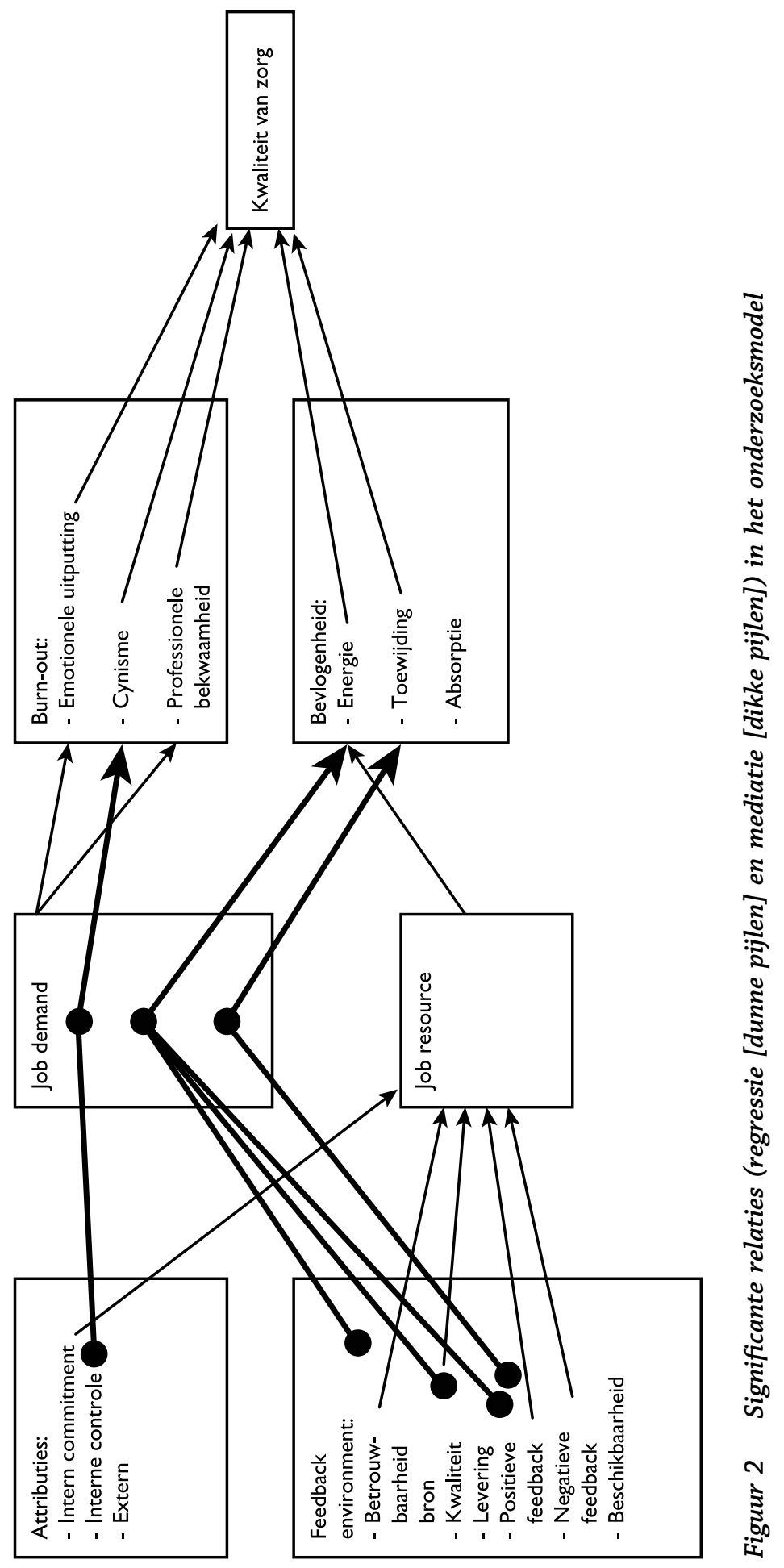




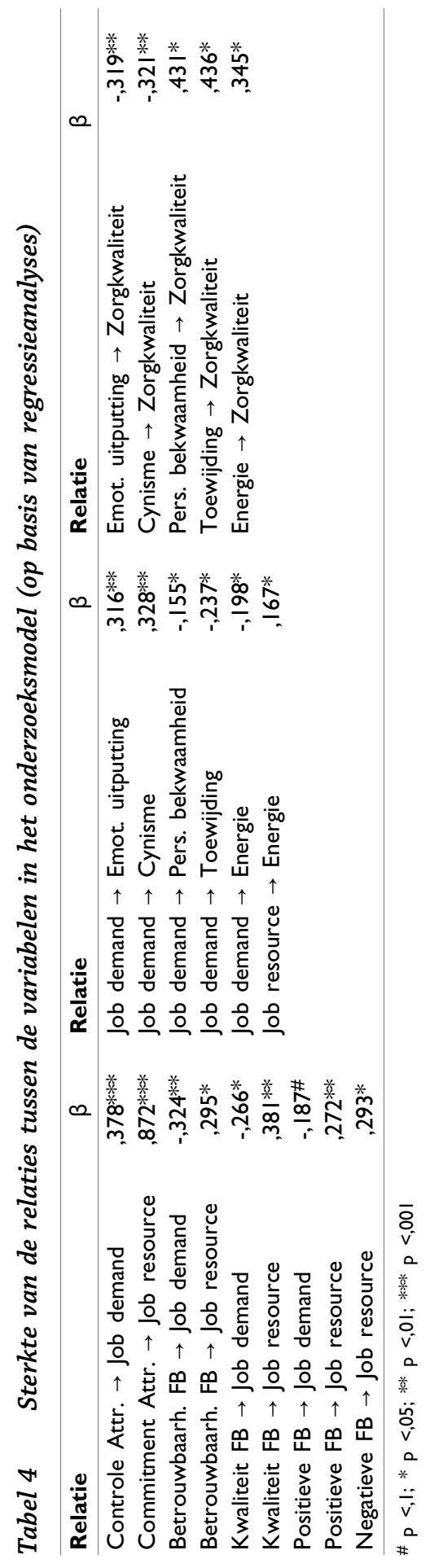


Uit de mediatie-analyses (zie de dikke pijlen in figuur 2) blijkt dat met name de ervaring van de feedback als job demand medieert tussen attributie of feedbackomgeving en de welzijnsdimensies. De ervaring van de feedback als job resource speelt geen rol als mediator. Evenmin spelen de welzijnsdimensies een mediërende rol tussen job demands of resources en de ervaren zorgkwaliteit. De bovenste dikke pijlen in figuur 2 betekenen dat hoe meer de verpleegkundigen de feedback als controle attribueren, hoe hoger de score op cynisme omdat de feedback wordt ervaren als een job demand.

De middelste dikke pijlen betekenen dat een hogere betrouwbaarheid van de feedbackbron, een betere kwaliteit van de feedback en hoe beter er positieve feedback wordt gegeven, leiden tot meer energie, omdat feedback dan minder als een job demand wordt ervaren. Op dezelfde manier leidt het beter geven van positieve feedback tot meer toewijding (onderste dikke pijlen in figuur 2). Al deze significante mediatieresultaten horen bij het eerste deel (kader A) van het model in figuur 1 . Geen enkele van de mediatieanalyses bij het tweede deel (kader B) bleek significante indirecte relaties tussen job demands en job resources enerzijds en zorgkwaliteit anderzijds (via de welzijnsdimensies) op te leveren. Dat komt doordat de ervaring van de feedback als een job demand of juist als een job resource niet significant samenhangt met de ervaren kwaliteit van zorg.

Omdat de ervaring van feedback als een job demand of juist als een job resource niet significant samenhangt met de kwaliteit van de zorg, en omdat deze ook niet altijd als mediator fungeren in de relatie tussen attributies en feedbackomgeving enerzijds en welzijn anderzijds, hebben we ook analyses uitgevoerd met verbanden tussen attributies en feedbackomgeving als onafhankelijke variabelen en kwaliteit van zorg als afhankelijke variabele. Hoewel we deze directe relatie niet veronderstellen in ons model blijken er wel enkele significante directe relaties te zijn. Daaruit blijkt dat de betrouwbaarheid van de feedbackbron $(\beta=$ ,285; $p<, 05)$, de kwaliteit van de feedback $(\beta=, 281 ; p<, 01)$, de beschikbaarheid van feedback $(\beta=, 267 ; p<, 01)$, en de commitment-attributie $(\beta=, 312 ; p<, 01)$ significant samenhangen met de ervaren kwaliteit van zorg. Deze relaties worden niet gemedieerd door de ervaring van feedback als job demand of resource, of door de welzijnsdimensies.

\section{Conclusie}

De resultaten van deze kwantitatieve studie laten zien dat in de ziekenhuisafdelingen waar feedback over kwaliteitsindicatoren werd ingevoerd, dit niet leidde tot een beter welzijn van de verpleegkundigen en tot een betere kwaliteit van zorg, gemeten aan de hand van de beleving van de verpleegkundigen zelf. De lagere score op de ervaren kwaliteit van zorg na de interventie kan te wijten zijn aan het feit dat de verpleegkundigen, door de feedback die ze krijgen, zich bewust worden van de tekortkomingen in de zorg die ze leveren en daardoor de kwaliteit lager beoordelen. De significant lagere scores op de welzijnsdimensies kunnen komen doordat de feedback zich richt op de kwantitatief meetbare kwaliteit van zorg, zoals dat wordt gevraagd door externe partijen. De externe attributie is de hoogste attributiescore (5,8 op een schaal van 1-7). Dit heeft 
een vervreemdend effect op de verpleegkundigen, omdat het de aandacht afleidt van de kwalitatieve zorg voor de patiënten (Doherty, 2009; Struijs \& Vathorst, 2009). Daarnaast kan de nadruk op enkele kwantitatieve kwaliteitsindicatoren ervoor zorgen dat de verpleegkundigen minder tijd hebben voor zaken die volgens hen veel belangrijker zijn in de kwaliteit van zorg.

Daar staat tegenover dat de resultaten ook laten zien dat de manier waarop de feedback wordt ervaren (als een job demand of juist als een resource), waarom de feedback wordt gegeven (attributie), en de feedbackomgeving, met name de rol van de leidinggevende daarin, van invloed zijn op het welzijn van de verpleegkundigen en op de kwaliteit van de zorg. In de eerste plaats zijn de resultaten in lijn met de verwachting dat de attributies over het waarom van de feedback van invloed zijn op het ervaren van de feedback als een job demand of juist als een resource. Als de verpleegkundigen denken dat de feedback werd ingevoerd om de verpleegkundigen beter te kunnen controleren (controle-attributie), dan wordt de feedback meer als een extra belasting ervaren (dus als een job demand). Als de verpleegkundigen daarentegen denken dat de feedback werd ingevoerd om hen te ondersteunen bij hun werk (commitment-attributie), dan wordt de feedback juist meer als ondersteunend ervaren (dus als een job resource). De externe attributie komt in de vier afdelingen het meeste voor. Hierbij denken verpleegkundigen dat de feedback werd ingevoerd vanwege verplichtingen van buiten het ziekenhuis (bijvoorbeeld opgelegd door de Inspectie Gezondheidszorg of zorgverzekeraars). Deze attributie zorgt voor de ervaring van de feedback als een job demand. De externe attributie is echter niet gerelateerd aan het welzijn van de verpleegkundigen en hoe zij de kwaliteit van de zorg binnen hun afdeling beoordelen (noch direct, noch indirect). Daarmee speelt deze attributie geen rol voor het welzijn van de verpleegkundigen of voor de kwaliteit van de zorg.

Ten tweede speelt de feedbackomgeving een belangrijke rol in het verklaren van het welzijn van de verpleegkundigen en de kwaliteit van de zorg, zowel direct als indirect. Het indirecte effect van de feedbackomgeving loopt vooral via de ervaring van de feedback over kwaliteitsindicatoren als een job demand; hoe beter de feedbackomgeving, hoe minder de feedback over kwaliteitsindicatoren wordt ervaren als een job demand, en hoe beter het welzijn en hoe beter de kwaliteit van de zorg. Van de feedbackomgeving zijn vooral de dimensies betrouwbaarheid van de feedbackbron en kwaliteit van de feedback van belang. Dit betekent dat een betrouwbaar ervaren leidinggevende die goede feedback geeft, kan zorgen voor meer welzijn van de verpleegkundigen (minder burn-out en meer bevlogenheid), omdat de feedback over kwaliteitsindicatoren dan minder als een (extra) belasting (dus als een job demand) wordt ervaren. Daarnaast is een als betrouwbaar ervaren leidinggevende die goede feedback geeft, ook direct van invloed op de beoordeling van de kwaliteit van de zorg.

Een derde conclusie uit de resultaten is dat de rol van het ervaren van feedback als job resource slechts een beperkte rol speelt als mediërende variabele. Het ervaren van feedback als job demand blijkt een veel sterker mediërend effect te hebben in de relaties tussen attributies en feedbackomgeving aan de ene kant en de onderscheiden dimensies van welzijn aan de andere kant. Voor burn-out als afhankelijke variabele is dit, conform het JD-R model, een verwachte uitkomst. Maar voor bevlogenheid als de afhankelijke variabele is deze uitkomst niet in lijn met de verwachtingen van het JD-R model (Demerouti et al., 2001), waarin 
een positief effect van job resources op bevlogenheid wordt verondersteld; en geen of een negatief (maar kleiner) effect van job demands op bevlogenheid. Deze resultaten zijn wel in lijn met de resultaten uit een meta-studie van Crawford et al. (2010), waaruit blijkt dat als hinderlijk ervaren job demands wel degelijk een negatief effect op bevlogenheid kunnen hebben.

In de vierde plaats blijkt het ervaren van de feedback als een job demand of als een job resource niet van invloed op de beoordeling van de kwaliteit van de zorg; noch direct, noch indirect. Het ervaren van de feedback als een job demand is wel van invloed op burn-out en bevlogenheid, en deze beide welzijnsaspecten zijn weer van invloed op de beoordeling van de kwaliteit van zorg, maar het mediatiemodel in zijn geheel is niet statistisch significant. Deze uitkomst betekent dat we er niet zomaar van uit kunnen gaan dat de manier waarop feedback wordt ervaren (als een job demand of als een resource), via het vergroten van het welzijn van de verpleegkundigen, de kwaliteit van zorg verbetert. Mogelijk spelen andere factoren ook een rol in dit proces. Daarom moet worden gezocht naar andere manieren om via een positieve beïnvloeding van het welzijn de kwaliteit van de zorg te verbeteren. De feedbackomgeving blijkt in deze studie belangrijk te zijn. Dat wil zeggen dat de manier waarop er in het algemeen met feedback wordt omgegaan (ook wel de feedbackcultuur genoemd; de manier waarop feedback wordt gegeven, de timing en kwaliteit van de feedback, de rol van de leidinggevende daarin, de verwerking van de feedback naar acties, etc.) van belang is bij het interpreteren en verwerken van de feedback over kwaliteitsindicatoren. In een feedbackomgeving waarin het heel gewoon of normaal is om feedback te geven en te ontvangen, wordt feedback minder als een belasting ervaren en zal deze dus een positief effect hebben op het welzijn.

Ten slotte is een belangrijke conclusie dat verpleegkundigen met minder burnout-verschijnselen en meer bevlogenheid de kwaliteit van de zorg zelf hoger beoordelen. Dit bevestigt de rol van het welzijn van verpleegkundigen voor de gepercipieerde kwaliteit van de zorg. Of dit ook opgaat voor een meer objectieve maat voor zorgkwaliteit, kunnen we op basis van deze studie niet aangeven. Daarvoor is verder onderzoek, gebruikmakend van objectieve kwaliteitscriteria, noodzakelijk.

Op basis van de bovenstaande conclusies blijft de vraag hoe het komt dat tijdens de periode van frequente feedback over kwaliteitsindicatoren, het welzijn van de verpleegkundigen en hun beoordeling van de kwaliteit van zorg is afgenomen. In de eerste plaats kunnen er naast de implementatie van de feedback andere ontwikkelingen hebben plaatsgevonden die deze effecten zouden kunnen verklaren. Naast de eerdergenoemde mechanismen van bewustwording en een focus op kwantitatieve criteria zou er ook sprake kunnen zijn van andere sectorbrede ontwikkelingen (zoals de voortdurende focus op bezuinigingen), want de resultaten gelden voor vier afdelingen in drie verschillende, doch vergelijkbare, ziekenhuizen in verschillende delen van het land. Een andere mogelijke verklaring is dat de implementatie van de feedback als proces niet helemaal soepel is verlopen. De resultaten laten zien dat de manier waarop de feedback wordt gegeven en de rol van de leidinggevende daarin (feedbackomgeving) van belang zijn voor de ervaring van de feedback en als determinant van welzijn en kwaliteit. 


\section{Discussie en aanbevelingen}

De resultaten en conclusies van dit onderzoek zijn gebaseerd op de gegevens van 77 verpleegkundigen die werkzaam zijn in vier afdelingen van drie ziekenhuizen. Daarmee zijn deze conclusies niet per definitie generaliseerbaar naar alle ziekenhuizen. Een belangrijk kenmerk van onze onderzoekspopulatie is de hoge mate van bevlogenheid (toewijding) en intrinsieke betrokkenheid bij de aard van het werk en bij de zorg voor patiënten. Alle interventies die ingrijpen in de manier van werken, zullen worden afgewogen in het licht van wat dat betekent voor de zorg voor de patiënten. Daarmee zijn de conclusies specifiek van toepassing op de ziekenhuiszorg, maar wellicht ook op andere vormen van zorg.

Een tekortkoming van het onderzoek is dat de meer precieze effecten van de invoering van de feedback niet goed kan worden vastgesteld door het ontbreken van een controlegroep. Met een controlegroep hadden we met meer overtuiging kunnen aangeven of er mogelijk andere verklaringen zouden kunnen zijn voor de afname van het welzijn en de beoordeling van de kwaliteit van de zorg.

Ook is het aantal respondenten in deze studie aan de lage kant. De opzet van het onderzoek met twee metingen geeft weliswaar meer vertrouwen in de richting van het verband, maar met een grotere populatie uit meer afdelingen en ziekenhuizen hadden we sterkere conclusies kunnen formuleren, en hadden we een beter inzicht gehad in de generaliseerbaarheid van onze uitkomsten. Desondanks zijn de resultaten en conclusies voor verder onderzoek relevant, want ze geven een bevestiging van de mediërende rol van medewerkerswelzijn. Daarnaast versterken de resultaten het beeld dat de feedback als zodanig niet van belang is voor de kwaliteit van de zorg, maar dat het meer de manier is waarop de feedback wordt gegeven en ervaren, die in dit opzicht bepalend is. Dit sluit aan bij het werk van bijvoorbeeld Bowen en Ostroff (2004), die erop wijzen dat een sterk systeem waarin HR-activiteiten eenduidig worden ervaren, tot een betere beleving en resultaten leidt.

Voor de praktijk in de zorgsector zijn de resultaten en conclusies interessant, omdat ze laten zien dat via beïnvloeding van het welzijn van de verpleegkundigen de kwaliteit van de zorg kan worden verbeterd. Interventies waarin aandacht wordt besteed aan hoe deze worden geïmplementeerd en welke rol de leidinggevende daarin speelt, kunnen een positief effect hebben op de kwaliteit van de zorg. Feedback kan dus wel een positieve bijdrage leveren aan het verbeteren van het welzijn van verpleegkundigen en de kwaliteit van de door hen geleverde zorg, mits de feedback wordt gebracht als een manier om het werk beter te kunnen uitvoeren of als een middel om de werkbelasting te verlagen. Daarnaast is het van belang dat er aandacht wordt besteed aan het uitleggen van het waarom van de feedback en aan de manier waarop de feedback wordt gegeven, hoe betrouwbaar de feedback is, en de kwaliteit van de verstrekte informatie. Ten slotte is het van belang om niet alleen op kwantitatief meetbare aspecten te focussen, maar ook aandacht te besteden aan minder goed in getallen uit te drukken aspecten van het werk, zoals het geruststellen van patiënten. 


\section{Bijlage: Detailoverzicht van significante relaties in het onderzoeksmodel}

Uit de regressieanalyses komen de volgende resultaten naar voren:

\section{Attributies $\rightarrow$ job demands, job resources}

- Hoe meer verpleegkundigen de feedback als controle attribueren, hoe meer de feedback als job demand wordt ervaren $(\beta=, 378 ; p<, 001)$.

- Hoe meer de verpleegkundigen de feedback als ondersteuning (commitment) attribueren, hoe meer de feedback als job resource wordt ervaren $(\beta=, 872$; $p<, 001)$.

\section{Feedbackomgeving $\rightarrow$ job demands, job resources}

- Hoe meer de leidinggevende als een betrouwbare bron voor feedback wordt ervaren, hoe minder de feedback wordt ervaren als job demand $(\beta=-, 324 ; p$ $<, 01)$ en hoe meer de feedback wordt ervaren als job resource $(\beta=, 295 ; p<$ ,05).

- Hoe hoger de kwaliteit van de feedback wordt bevonden, hoe minder de feedback wordt ervaren als job demand $(\beta=-, 266 ; p<, 05)$ en hoe meer de feedback wordt ervaren als job resource $(\beta=, 381 ; p<, 01)$.

- Hoe beter de ervaring met positieve feedback van de leidinggevende, hoe meer de feedback wordt ervaren als job resource $(\beta=, 272 ; p<, 01)$.

- Hoe beter de ervaring met negatieve feedback van de leidinggevende, hoe meer de feedback wordt ervaren als job resource $(\beta=, 293 ; p<, 05)$.

Job demands, job resources $\rightarrow$ welzijn

- Hoe meer de feedback wordt ervaren als een job demand, hoe hoger de score op emotionele uitputting $(\beta=, 316 ; p<, 01)$ en cynisme $(\beta=, 328 ; p<, 01)$, en hoe lager de score op persoonlijke bekwaamheid $(\beta=-, 155 ; p<, 05)$.

- Hoe meer de feedback wordt ervaren als een job demand, hoe lager de score op energie $(\beta=-, 198 ; p<, 05)$ en toewijding $(\beta=-, 237 ; p<, 05)$.

- Hoe meer de feedback wordt ervaren als een job resource, hoe hoger de score op energie $(\beta=, 167 ; p<, 05)$.

- De beoordeling van de kwaliteit van de zorg hangt significant samen met de burn-outdimensies emotionele uitputting $(\beta=-319 ; p<, 01)$, cynisme $(\beta=$ -,321; $p<, 01)$, en persoonlijke bekwaamheid $(\beta=, 431 ; p<, 05)$, en met de bevlogenheidsdimensies energie $(\beta=, 345 ; p<, 05)$ en toewijding $(\beta=, 436$; $p<, 05)$.

Uit de mediatieanalyses komen de volgende significante resultaten:

Attributies $\rightarrow$ job demands $\rightarrow$ burn-out

- Job demands mediëren volledig de relatie tussen de controle-attributie en cynisme: hoe meer de verpleegkundigen de feedback als controle attribueren, hoe meer de feedback wordt ervaren als een job demand $(\beta=, 428 ; p<, 001)$, 
en een hogere score voor job demands leidt tot een hogere score op cynisme $(\beta=, 222 ; p<, 05)$. Het indirecte effect van controle-attributie op cynisme is 0,095 (95\% betrouwbaarheidsinterval (BI): 0,015 - 0,203).

\section{Feedbackomgeving $\rightarrow$ job demands $\rightarrow$ burn-out}

- Ondanks de significante relaties tussen kwaliteit van de feedback, job demands en cynisme is het mediatiemodel niet significant, maar er is wel een significant effect van de kwaliteit van feedback op cynisme $(\beta=-, 192 ; p<, 05)$.

- Ook de relatie tussen de ervaring met positieve feedback en cynisme verloopt niet indirect via job demands, maar is direct $(\beta=-, 153 ; p<, 05)$.

- De relatie tussen betrouwbaarheid van de feedbackbron en emotionele uitputting wordt niet gemedieerd door job demands, maar is direct $(\beta=-, 284 ; p<$ ,01).

- De relatie tussen kwaliteit van de feedback en emotionele uitputting wordt niet gemedieerd door job demands, maar is direct $(\beta=-, 247 ; p<, 01)$.

\section{Feedbackomgeving $\rightarrow$ job demands $\rightarrow$ bevlogenheid}

- Job demands mediëren volledig de relatie tussen betrouwbaarheid van de feedbackbron en energie: hoe betrouwbaarder de feedbackbron, hoe minder de feedback wordt ervaren als job demand $(\beta=-, 352 ; p<, 05)$ en een hogere score voor job demands leidt tot minder energie $(\beta=-, 129 ; p<, 05)$. Het indirecte effect van betrouwbaarheid van de feedbackbron op energie is 0,045 (95\% BI: 0,008 - 0,141).

- Job demands mediëren volledig de relatie tussen kwaliteit van de feedback en energie: hoe hoger de kwaliteit van de feedback, hoe minder de feedback wordt ervaren als een job demand $(\beta=-, 292 ; p<, 05)$ en een hogere score voor job demands leidt tot minder energie $(\beta=-, 133 ; p<, 05)$. Het indirecte effect van betrouwbaarheid van de feedbackbron op energie is 0,039 (95\% BI: $0,005-0,114)$.

- Job demands mediëren volledig de relatie tussen de ervaring met positieve feedback en energie: hoe beter de ervaring met positieve feedback, hoe minder de feedback wordt ervaren als een job demand $(\beta=-, 237 ; p<, 05)$ en een hogere score voor job demands leidt tot minder energie $(\beta=-, 132 ; p<, 05)$. Het indirecte effect van betrouwbaarheid van de feedbackbron op energie is 0,031 (95\% BI: 0,004-0,086).

- Job demands mediëren volledig de relatie tussen de ervaring met positieve feedback en toewijding: hoe beter de ervaring met positieve feedback, hoe minder de feedback wordt ervaren als job demand $(\beta=-, 237 ; p<, 05)$ en meer job demands leidt tot minder energie $(\beta=-, 124 ; p<, 1)$. Het indirecte effect van betrouwbaarheid van de feedbackbron op energie is 0,029 (95\% BI: 0,002 $-0,097)$.

Job demands, job resources $\rightarrow$ welzijn $\rightarrow$ kwaliteit van zorg

- De mediatieanalyses tussen enerzijds job demands en job resources en anderzijds kwaliteit van de zorg via de dimensies van burn-out en bevlogenheid 
(dit betreft het tweede deel van de analyses) zijn niet significant. Dat komt doordat de ervaring van de feedback als een job demand of juist als een job resource niet significant samenhangt met de kwaliteit van zorg. Er zijn wel significante relaties van de burn-outdimensies emotionele uitputting $(\beta=-, 245$; $p<, 05)$ en professionele bekwaamheid $(\beta=, 366 ; p<, 1)$ met kwaliteit van zorg, en van de bevlogenheidsdimensie toewijding $(\beta=, 374 ; p<, 01)$ met kwaliteit van zorg.

\section{Noot}

1 Door een coderingsfout is de laatste dimensie (aanmoedigen van feedbackzoekgedrag) in de dataverzameling weggevallen. In de analyses wordt daarom met zes in plaats van zeven dimensies gewerkt.

\section{Literatuur}

Aiken, L.H., Sloane, D.M., Bruyneel, L., Van den Heerde, K., Griffiths, P., Busse, R., et al. (2014). Nurse staffing and education and hospital mortality in nine European countries: A retrospective observational study. The Lancet, 383, 1824-1830.

Anseel, F. \& Lievens, F. (2007). The long-term impact of the feedback environment on job satisfaction: A field study in a Belgium context. Applied Psychology: An International Review, 56(2), 254-266.

Baron, R.M. \& Kenny, D.A. (1986). The moderator-mediator variable distinction in social psychological research: Conceptual, strategic, and statistical considerations. Journal of personality and social psychology, 51(6), 1173-1182.

Berwick, D.M., James, B. \& Coye, M.J. (2003). Connections between quality measurement and improvement. Medical Care, 41(1), I-30 - I-38.

Botje, D., Ten Asbroek, G., Plochg, T., Anema, H., Kringos, D.S., Fischer, C., et al. (2016). Are performance indicators used for hospital quality management: A qualitative interview study amongst health professionals and quality managers in The Netherlands. BMC Health Services Research, 16, 574. doi:10.1186/s12913-016-1826-3

Bowen, D.E. \& Ostroff, C. (2004). Understanding HRM-firm performance linkages: The role of 'strength' of the HRM system. Academy of Management Review, 29(2), 203221.

Boxall, P. \& Macky, K. (2009). Research and theory on high-performance work systems: Progressing the high-involvement stream. Human Resource Management Journal, 19(1), 3-23.

Crawford, E.R., LePine, J.A. \& Rich, B.L. (2010). Linking job demands and resources to employee engagement and burnout: A theoretical extension and meta-analytic test. Journal of Applied Psychology, 95, 834-848.

Dahling, J.J., Chau, S.L. \& O'Malley, A. (2012). Correlates and consequences of feedback orientation in organizations. Journal of Management, 38(2), 531-546.

De Jonge, J. \& Schaufeli, W.B. (1998). Job characteristics and employee well-being: A test of Warr's Vitamin Model in health care workers using structural equation modelling. Journal of Organizational Behavior, 19, 387-407.

Demerouti, E., Bakker, A.B., Nachreiner, F. \& Schaufeli, W.B. (2001). The job demandsresources model of burnout. Journal of Applied Psychology, 86, 499-512.

De Vos, M., Graafmans, W., Kooistra, M., Meijboom, B., Van der Voort, P. \& Westert, G. (2009). Using quality indicators to improve hospital care: A review of the literature. International Journal for Quality in Health Care, 21(2), 119-129. 
Doherty, C. (2009). A qualitative study of health service reform on nurses' working lives: Learning from the UK National Health Service (NHS). International Journal of Nursing Studies, 46, 1134-1142.

Flottorp, S.A., Jamtvedt, G., Gibis, B. \& McKee, M. (2010). Using audit and feedback to health professionals to improve the quality and safety of health care. Copenhagen, Denmark: The Regional Office for Europe of the World Health Organization.

Franco, L., Bennet, S. \& Kanfer, R. (2002). Health sector reform and public sector health worker motivation: A conceptual framework. Social Science and Medicine, 54, 12551266.

Giesbers, A.P.M., Schouteten, R.L.J., Poutsma, E., Van der Heijden, B.I.J.M. \& Van Achterberg, T. (2013). Feedback provision, nurses' well-being, and quality improvement: Towards a conceptual framework. Journal of Nursing Management, 23(5), 682-691.

Giesbers, A.P.M., Schouteten, R.L.J., Poutsma, E., Van der Heijden, B.I.J.M. \& Van Achterberg, T. (2014). Nurses' perception of feedback on quality measurements: Development and validation of a measure. Zeitschrift für Personalforschung, 28(3), 391-398.

Guest, D. (2002). Human resource management, corporate performance and employee well-being: Building the worker into HRM. Journal of Industrial Relations, 44(3), 335358.

Hasselhorn, H.M., Conway, P.M., Widerszal-Bazyl, M., et al. (2008). Contribution of job strain to nurses' consideration of leaving the profession: Results from the longitudinal European nurses' early exit study. Scandinavian Journal of Work, Environment and Health, 6, 75-82.

Ikkersheim, D.E. \& Koolman, X. (2012). Dutch healthcare reform: did it result in better patient experiences in hospitals? A comparison of the consumer quality index over time. BMC Health Services Research, 12, 76. doi:10.1186/1472-6963-12-76

Inspectie voor de Gezondheidszorg (2017). Basisset Medisch Specialistische Zorg; Kwaliteitsindicatoren 2017. Utrecht: Inspectie voor de Gezondheidszorg, Ministerie van Volksgezondheid, Welzijn en Sport.

Ivers, N., Jamtvedt, G., Flottorp, S., Young, J.M., Odgaard-Jensen, J., French, S.D., O’Brien, M.A., Johansen, M., Grimshaw, J. \& Oxman, A.D. (2012). Audit and feedback: effects on professional practice and healthcare outcomes (Review). Cochrane Database of Systematic Reviews 2012 (6). doi:10.1002/14651858.CD000259.pub3

Kluger, A.N. \& DeNisi, A. (1996). The effects of feedback interventions on performance: A historical review, a meta-analysis, and a preliminary feedback intervention theory. Psychological Bulletin, 119(2), 254-284.

Le Blanc, P.M., De Jonge, J., De Rijk, A.E. \& Schaufeli, W.B. (2001). Well-being of intensive care nurses (WEBIC): A job analytic approach. Journal of Advanced Nursing, 36, 460-470.

Mark, G. \& Smith, A.P. (2012). Occupational stress, job characteristics, coping, and the mental health of nurses. British Journal of Health Psychology, 17(3), 505-521.

McCann, L., Granter, E., Hassard, J. \& Hyde, P. (2015). 'You can't do both - something will give': limitations of the targets culture in managing UK health care workforces. Human Resource Management, 54(5), 773-791.

Nishii, L.H., Lepak, D.P. \& Schneider, B. (2008). Employee attributions of the 'why' of HR practices: Their effects on employee attitudes and behaviours, and customer satisfaction. Personnel Psychology, 61, 503-545.

Paauwe, J. (2009). HRM and performance: achievements, methodological issues and prospects. Journal of Management Studies, 46(1), 129-142.

Paauwe, J., Wright, P.M. \& Guest, D. (2013). HRM and performance: What do we know and where should we go? In J. Paauwe, D.E. Guest \& P.M. Wright (Eds.), HRM \& performance: achievements and challenges (pp. 1-13), West Sussex: John Wiley \& Sons.

Peccei, R., Van de Voorde, K. \& Van Veldhoven, M. (2013). HRM, well-being and performance: A theoretical and empirical review. In J. Paauwe, D.E. Guest \& P.M. Wright (Eds.), HRM \& performance: achievements and challenge (pp. 15-45), West Sussex: John Wiley \& Sons.

Rosen, C.C., Levy, P.E. \& Hall, R.J. (2006). Placing perceptions of politics in the context of the feedback environment, employee attitudes, and job performance. Journal of Applied Psychology, 91, 211-220. 
Schaufeli, W.B. \& Bakker, A.B. (2003). Utrecht work engagement scale: preliminary manual. Utrecht: Occupational Health Psychology Unit Utrecht University.

Schaufeli, W.B. \& Bakker, A.B. (2004). Job demands, job resources, and their relationship with burnout and engagement: A multi-sample study. Journal of Organizational Behavior, 25, 293-315.

Steelman, L.A., Levy, P.E. \& Snell, A.F. (2004). The feedback environment scale: construct definition, measurement, and validation. Educational and Psychological Measurement, 64(1), 165-184.

Struijs, A. \& Vathorst, S.V. (2009). Dilemma's van verpleegkundigen en verzorgenden. Den Haag: Centrum voor Ethiek en Gezondheid.

Van der Veer, S.N., De Keizer, N.F., Ravelli, A.C.J., Tenkink, S. \& Jager, K.J. (2010). Improving quality of care: A systematic review on how medical registries provide information feedback to health care providers. International Journal of Medical Informatics, 79, 305-323. 